\title{
Strategi Public Relations dalam Membangun Citra Perusahaan Melalui Pameran Indonesia International Motor Show (IIMS)
}

\author{
Fitri Rahmadani ${ }^{1}$, Susi Andrini ${ }^{2}$ \\ ${ }^{1,2}$ Program Studi Ilmu Komunikasi Sekolah Tinggi Ilmu Komunikasi InterStudi \\ Jakarta \\ rahmadani.fira02@gmail.com; ussie69@gmail.com
}

Received: November 5, 2020; Revised: February 20, 2021; Accepted: February 23, 2021

\begin{abstract}
Abstrak
Untuk menjawab tantangan dan semakin banyaknya persaingan dalam bidang produk otomotif di tanah air, seperti sepeda motor. Seorang Public Relations Officer dituntut keahlian dan inovasinya untuk menyusun strategi perencanaan Public Relations agar dapat membangun citra perusahaan. Salah satu fungsi Public Relations yang dilaksanakan, adalah special event dalam bentuk program pameran Indonesia International Motor Show (IIMS) merupakan pameran otomotif bergengsi, dan produk sepeda motor yang dipromosikan adalah KTM \& Husqvarna. Tujuan penelitian adalah untuk menjelaskan strategi Public Relations dalam membangun citra perusahaan melalui pameran IIMS. Konsep yang digunakan fase strategi perencanaan Public Relations yang dikemukakan oleh Cutlip, Center dan Broom. Pendekatan yang digunakan dalam penelitian ini adalah kualitatif dengan jenis penelitian deskriptif yang menggambarkan realitas yang ada tanpa mencari hubungan antar variabel. Pengumpulan data dilakukan melalui observasi partisipan, wawancara mendalam, dokumentasi dan internet untuk memperoleh informasi atau data yang mendalam dan relevan dalam penelitian. Untuk menganalisis data dilakukan melalui tahap reduksi data, penyajian dan verifikasi atau simpulan. Hasil penelitian menunjukkan bahwa setiap fase dalam proses perencanaan strategi Public Relations mendukung penelitian ini dalam membangun citra perusahaan. Terbukti dengan banyak nya pengunjung yang datang ke stand KTM \& Husqvarna, Peliputan media serta memperoleh penghargaan dalam kategori Exhibiton Participant.Temuan dalam penelitian adalah strategi komunikasi terintegrasi.
\end{abstract}

Kata kunci: Citra, Pameran, Public Relations ,Strategi, Strategi Public Relations. 


\begin{abstract}
To answer the challenges and the increasing competition in the field of automotive products in the country, such as motorbikes. A Public Relations Officer is required to be skilled and innovative in formulating a Public Relations planning strategy in order to build a company image. One of the Public Relations functions carried out is a special event in the form of the Indonesia International Motor Show (IIMS) exhibition program, a prestigious automotive exhibition, and the motorcycle products being promoted are KTM \& Husqvarna. The research objective is to explain the Public Relations strategy in building corporate image through the IIMS exhibition. The concept used in the Public Relations planning strategy phase put forward by Cutlip, Center and Broom. The approach used in this research is qualitative with descriptive type of research that describes the existing reality without looking for relationships between variables. Data collection was carried out through participant observation, in-depth interviews, documentation and the internet to obtain in-depth and relevant information or data in research. To analyze the data, it is done through the stages of data reduction, presentation and verification or conclusions. The results showed that each phase in the process of planning the Public Relations strategy supported this research in building the company image. Evidenced by the many visitors who came to the KTM \& Husqvarna stand, media coverage and received awards in the Exhibiton Participant category. The findings in the research were an integrated communication strategy.
\end{abstract}

Keywords: image,exhibition, Public Relations,Strategy, Public Relations strategy

\section{Pendahuluan}

Aktivitas komunikasi perusahaan dalam prosesnya dapat berlangsung melalui komunikasi internal dan komunikasi eksternal yang menghubungkan bagaimana peran dan fungsi Public Relations (PR) dalam suatu perusahaan. PT Premium Motorindo Abadi merupakan perusahaan Importir atau Agen Pemegang Merek (APM) yang mendistribusikan dan memasarkan produk Motorcycle dengan nama merek Husquarna dan KTM di Indonesia. Dalam pengembangan bisnisnya sebagai produsen otomotif terkemuka di bidang Offroad
Motorcycle kemudian merambah menjadi produsen motor Listrik ( $E$ Motorcycle) pada level nasional maupun internasional. Dengan menggandeng nama besar dua merek motor "Husqvarna" yang didirikan sejak tahun 1903 di negara Swedia dan merek "KTM" didirikan sejak tahun 1934 di kota Mattighoven, Austria. Selanjutnya melakukan pemasaran produk motorcycle Husqvarna dan KTM dengan dua jenis produk yaitu Offroad dan Streetbike. Dalam prosesnya, melaksanakan komunikasi internal dan eksternal 
yang dilakukan dengan berbagai program komunikasi yang terencana dan ter-koordinir dengan baik dimana tujuannya adalah membangun citra perusahaan. Oleh karena itu, penting menerapkan strategi komunikasi dan memiliki peran aktif dalam proses pengambilan keputusan.

Dengan cara ini, semua elemen komunikasi internal dan eksternal dapat muncul menciptakan efek komunikasi yang efektif. Fungsi manajemen komunikasi perusahaan, berisi penanganan Public Relations, komunikasi internal, interaksi pemegang saham, iklan korporat. Semua fungsi ini menyiratkan komunikasi dengan stakeholder yang dapat ditangani dan dikendalikan secara langsung. Biasanya, fungsi komunikasi dapat dengan mudah didorong, dikendalikan dan terbangunnya citra perusahaan (Van Riel \& Fombrun, 2007).

Salah satu kegiatan komunikasi perusahaan untuk membangun citra yang dilakukan oleh Public Relations Officer (PRO) PT Premium Motorindo Abadi adalah melaksanakan salah satu fungsi Public Relations yaitu special event dalam bentuk program pameran yang diselenggarakan oleh PT Dyandra Promosindo, dengan tajuk Indonesia International Motor Show (IIMS) Motobike pada tahun 2019. IIMS merupakan pameran otomotif bergengsi yang berlangsung di JIEXPO Kemayoran. Tujuannya adalah untuk menimbulkan kesadaran dan kepercayaan dari publik kepada perusahaan sehingga dapat membangun opini publik yang favourable dan citra positif perusahaan. Program pameran ini dilaksanakan untuk menjawab tantangan dan semakin banyaknya persaingan produk otomotif, seperti sepeda motor di tanah air sehingga penting untuk melakukan strategi dalam mempromosikan produk sepeda motor dengan merek Husqvarna dan KTM.

Turut sertanya mengikuti pameran IIMS pada 25 April 2019. PT Premium Motorindo Abadi secara resmi memperkenalkan sejumlah motor trail terbaru di ajang otomotif IIMS Motobike. Produk yang dipamerkan adalah sepeda motor dengan merek Husqvarna dan KTM.

Untuk melaksanakan program pameran IIMS tersebut diperlukan tahapan strategi yang dilakukan oleh Public Relations PT Premium Motorindo Abadi, agar produk merek motor yang dipamerkan dapat menimbulkan daya tarik pesan yang berbeda, tentunya dilakukan melalui komunikasi internal dalam bentuk koordinasi dengan divisi terkait sebelum melakukan komunikasi eksternal dalam bentuk pameran. Pameran dapat memberikan hasil yang sangat baik bagi PT Premium 
Motorindo Abadi jika praktisi Public

Relations memanfaatkan semua peluang yang mereka sajikan. Pameran bukan media Public Relations, tetapi alat jika digunakan untuk menciptakan kesadaran, meningkatkan citra dan reputasi serta untuk menjual produk. Pameran, meskipun mahal, adalah salah satu cara paling efektif untuk berkomunikasi dengan publik (Laricia, 2002). Public Relations PT Premium Motorindo Abadi harus mempertimbangkan bahwa orang mengunjungi pameran karena tiga alasan dasar. Pertama, untuk dihibur, kedua, untuk mengetahui bagaimana produk atau layanan baru benarbenar bekerja dan yang terakhir, kehadiran dapat berarti bahwa transaksi bisnis mungkin disepakati antara dua pihak. Oleh karena itu, Public Relations memainkan peran penting dalam semua ini. Public Relations PT Premium Motorindo Abadi perlu menyampaikan citra perusahaannya secara positif kepada para pengunjung, dan mempromosikan produk atau layanan apa pun yang ditawarkan, tanpa memaksa siapa pun untuk membeli produk atau layanan itu.

Beberapa penelitian yang telah dilakukan sebelumnya dan dianggap relevan, seperti penelitian yang dilakukan oleh (Lengkong et al., 2017) menemukan bahwa: (1) Strategi Public Relations memiliki peran dalam memulihkan citra Rumah Makan Kawan Baru yang dilakukan melalui evaluasi, penelaahan kembali, memperbaiki service atau pelayanan, dan melakukan musyawarah dan negosiasi kepada korban keracunan. (2) Strategi Public Relations memiliki peran dalam memulihkan citra Rumah Makan Kawan Baru dengan menggunakan media, seperti media online dan media cetak dengan memberikan penjelasan kasus, melakukan permohonan maaf kepada masyarakat guna memperoleh kembali simpati dari masyarakat. (3) Hasil penelitian (Mujianto, 2018) menunjukkan bahwa strategi Public Relations berpengaruh secara positif atau signifikan terhadap citra perusahaan hotel Grand Kopo Bandung. Penelitian lain yang dilakukan oleh (Putu et al., 2018) menunjukkan bahwa perubahan manajemen perusahaan BTDC menjadi ITDC mempengaruhi citra perusahaan sehingga citra kepedulian dengan ITDC memiliki kepercayaan yang terkait semua pemangku kepentingan terhadap ITDC. Strategi yang dilakukan oleh Public Relations ITDC dalam membangun citra perusahaan dilakukan melalui berbagai kegiatan. Seperti publikasi, berita, menginformasikan kepada publik, baik publik internal maupun eksternal, menggunakan media 
berbayar yang dalam bentuk acara, melakukan kontak sosial (keterlibatan masyarakat, lobi dan negosiasi melakukan kegiatan sosial (tanggung jawab sosial). Sementara penelitian yang dilakukan oleh Lenka Mikáčováa dan Petra Gavlakováa menunjukkan bahwa pengembangan strategi Public Relations yang sukses melibatkan empat elemen yaitu: Pertama, identifikasi berbagai atribut dan karakteristik citra, kedua, Persepsi semua pemangku kepentingan eksternal harus dinilai. Ketiga, fungsi komunikasi perusahaan. Keempat, Annual Public Relations yang terukur dan tahunan harus dibuat, ditopang oleh janji merek, dengan tujuan membentuk persepsi audiensi (Mikáčová \& Gavlaková, 2014). Hasil penelitian yang dilakukan oleh (Ruliana, Dwiantari, 2015) bahwa tahapan model perencanaan strategi Public Relations sebagai dasar pembentukan citra obyek wisata Sari Ater Hotel \& Resort.

Studi yang dilakukan oleh Senija (2015) menunjukkan antara lain, bahwa perusahaan konstruksi di B \& H sebagian besar belum mengembangkan strategi Public Relations secara khusus. Juga, mereka tidak mendekati citra perusahaan secara strategis, tetapi secara spontan, sporadis, dan secara intuitif. Ini berarti bahwa strategi yang lengkap perlu didasarkan pada setiap aturan profesional yang diketahui, dan itu menyiratkan keberadaan semua langkah strategis penting dalam pembuatannya. Profesional Public Relations harus "meyakinkan" manajer perusahaan mereka, dengan menggunakan argumen, bahwa strategi dan citra Public Relations adalah alat yang kuat dalam perjuangan melawan anonimitas di pasar. Public Relations dapat berkontribusi pada kualitas komunikasi perusahaan dan hasil total bisnis yang lebih baik. Perubahan sikap dengan manajer tentang strategi Public Relations tentu akan mengarah pada peran yang lebih besar bagi Public Relations dalam menjalankan bisnis perusahaan konstruksi di B\&H. Oleh karena itu, peran strategi hubungan masyarakat dalam menciptakan citra kelompok perusahaan ini masih belum memuaskan, juga tidak dapat dikatakan bahwa potensi bisnis cukup digunakan (Senija, Sehannovic, 2015).

Hasil penelitian seperti yang dijelaskan di atas, memiliki kesamaan dan perbedaan. Kesamaannya dalam penggunaan konsep yaitu strategi Public Relations dan citra perusahaan tetapi perbedaannya dalam subyek penelitian. Oleh karena itu tujuan dari penelitian ini adalah untuk menjelaskan strategi Public 
Relations dalam membangun citra melalui pameran IIMS.

\section{Kerangka Teori}

Definisi Public Relations

Cutlip, Center and Broom (2006) mendefinisikan bahwa "Public Relations is a management function that builds and maintains a mutually beneficial relationship between an organization and the community on which success or failure depends."

(Ruliana, 2014, Senija, 2015).

Ada beberapa frasa yang perlu diperhatikan dalam definisi mereka yang terkenal ini, pertama menggambarkan Public Relations sebagai 'fungsi manajemen', yang menyiratkan itu adalah tindakan yang terencana dan perencanaan yang memiliki hasil dalam pikiran. Ini diperkuat oleh 'identify, build and maintain', yang menunjukkan penelitian dan rangkaian kegiatan. 'Hubungan yang saling menguntungkan' berkaitan dengan proses komunikasi dua arah yang melalui organisasi akan bertindak untuk kepentingan dirinya sendiri dan kelompok atau masyarakat yang berinteraksi dengannya. Definisi ini melangkah lebih jauh dari yang lain dengan mendefinisikan publik sebagai orang-orang 'which depends on their success or failure'.

\section{Fungsi Public Relations}

Ada beberapa fungsi Public

Relations menurut booklet PRSA

(Public Relations Society of America) yaitu programming, relationship, writing and editing, information, production, special event seperti exhibiton atau pameran, speaking, research dan evaluation. (Ruliana, 2014).

Fungsi tersebut saling berkaitan dan tergantung konteks dalam melakukan kegiatan Public Relations.

\section{Strategi}

\begin{tabular}{lrrr}
\multicolumn{1}{c}{ Kata } & strategi & sering \\
digunakan oleh para & praktisi \\
komunikasi & perusahaan & untuk \\
menggambarkan & sesuatu & yang \\
'penting' seperti & dalam & pesan
\end{tabular}
strategis, arahan strategis atau untuk menggambarkan 'kegiatan'. Strategi dapat dilihat sebagai pemikiran, yaitu logika di balik tindakan (Robert, 1997). Drucker (dalam Kotler, 1988) melihatnya sebagai indikasi posisi suatu organisasi untuk masa depan, memutuskan apa yang harus dilakukan daripada bagaimana seharusnya dilakukan. Sedangkan menurut Porter (dalam Gibson, 1997) menyatakan bahwa strategi membutuhkan pilihan untuk memutuskan jenis nilai tertentu yang ingin diberikan oleh organisasi dan kepada khalayak. (Steyn, 2000) 


\section{Strategi Public Relations}

Di bidang pengamatan Public Relations, harus dimulai dari fakta bahwa misi dasar mengenai kegiatankegiatan ini adalah untuk membangun citra perusahaan. Namun, harus diperhitungkan bahwa citra perusahaan adalah hasil dari semua kegiatan "nyata" dan semua kegiatan komunikasi di mana perusahaan mentransmisikan yang diinginkan pesan ke grup publik yang relevan. Oleh karena itu, semua kegiatan bisnis tercermin melalui citra perusahaan, semua hal yang dilakukan oleh perusahaan. Apa yang dilakukan perusahaan dalam konteks kegiatan bisnis reguler mereka seringkali merupakan pesan yang lebih cepat dan lebih berpengaruh daripada apa yang disajikan kepada publik dengan menggunakan komunikasi yang dirancang khusus.

\section{Strategi Public Relations} rumit dan menantang, ini akan berhasil hanya jika dikembangkan sesuai dengan aturan disiplin dan tidak hanya oleh para profesional Public Relations, tetapi juga oleh para profesional dari disiplin lain yang akan memberikan pengetahuan ahli yang luas yang berlaku di bidang industri.

Strategi Public Relations dalam membangun citra perusahaan perlu melibatkan proses empat fase berikut untuk menyelesaikan masalah atau menciptakan kemungkinan (Broom \& Sha, 2013). Fase 1: Mendefinisikan masalah. Dalam fase ini pengetahuan, pendapat, sikap, dan perilaku semuanya terkait dengan prosedur dan kebijakan perusahaan diperiksa. Ini menciptakan dasar untuk semua fase lain dalam memecahkan masalah pengembangan citra. Fase 2: Perencanaan dan pemrograman Informasi yang dikumpulkan pada fase pertama digunakan untuk pengambilan keputusan tentang pemangku kepentingan, tujuan spesifik, gerakan dan strategi komunikasi, taktik dan tujuan umum. Itu berarti hasil dari fase pertama dimasukkan ke dalam kebijakan dan program perusahaan. Fase 3: Mengambil tindakan dan berkomunikasi. Dalam fase ini, program tindakan dan komunikasi yang harus mencapai tujuan spesifik untuk setiap publik sebagai prasyarat untuk realisasi tujuan umum program dilakukan. Fase 4: Evaluasi program. Dalam fase persiapan ini, implementasi dan hasil program dievaluasi. Penyesuaian didasarkan pada umpan balik pada efisiensi atau tidak ada efisiensi.

Untuk pendekatan penyusunan strategi PR, secara umum, setiap strategi berkualitas tinggi, seperti pertama, langkah penting - harus memiliki analisis 
situasi. Analisis ini akan memberikan pandangan yang jelas tentang situasi perusahaan atau masalah yang harus mereka atasi. Dalam strategi ini, titik krusialnya adalah menentukan target publik yang menjadi daya tarik perusahaan. Public Relations PT Premium Motorindo Abadi harus menentukan kepada siapa mereka tertarik, apa struktur dari setiap publik yang ditentukan; mereka harus melacak perubahan dan sikap di setiap kelompok yang ditentukan. Semua ini harus diintegrasikan dalam strategi Public Relations, untuk mencapai tujuan strategis, dengan pesan yang diarahkan, terencana dan jelas. Di bagian berikut, kita akan membahas apakah perusahaan PT Premium Motorindo Abadi memiliki strategi Public Relations, dan apakah mereka mengikuti aturan profesi sambil menciptakannya. Sebagai indikator "kebenaran" dari penciptaan strategi, untuk kebutuhan. Proses ini harus menjadi tugas dalam melakukan analisis situasi untuk setiap strategi Public Relations. Hasil yang disajikan akan membantu kita mendapatkan respons parsial pada sikap manajemen perusahaan PT Premium Motorindo Abadi tentang peran Public Relations dalam perusahaan.

\section{Citra Perusahaan}

Salah satu alasan mengapa citra perusahaan itu penting karena citra perusahaan adalah kategori strategis bisnis modern, dan ada konsensus ilmiah dan keahlian dalam pelaksanaannya. Untuk menjadi faktor keunggulan bisnis, citra harus berkualitas baik, yaitu positif, stabil, jelas, layak, dan mampu menghasilkan pertumbuhan dan perkembangan. Satu-satunya cara yang tepat untuk menciptakan dan memelihara citra yang menguntungkan untuk bisnis adalah pendekatan strategi Public Relations sebagai bagian dari strategi komunikasi perusahaan perlu memiliki peran yang sangat besar. Bahkan, di samping semua aspek kegiatan komunikasi (komunikasi manajemen, komunikasi pemasaran, dan berbagai konsep komunikasi organisasi) strategi Public Relations memiliki pengaruh terbesar pada citra perusahaan (Argenti, 2009).

Dapat dipahami bahwa perusahaan terkait dengan pengelolaan citra perusahaan. Ini menunjukkan bahwa ada korelasi positif yang kuat antara bagaimana orang memandang suatu organisasi dan perilaku pendukung perusahaan. Citra perusahaan dianggap sebagai gambaran mental suatu organisasi. Ini adalah jumlah total dari karakteristik yang dirasakan dari perusahaan, ini yang disebut sebagai citra perusahaan. Setiap organisasi memiliki citra apakah organisasi itu melakukan sesuatu terhadapnya atau 
tidak. Citra perusahaan dibentuk berdasarkan persepsi pemangku kepentingan atas tindakan perusahaan tertentu serta masalah industri dan bangsa terkait. Citra organisasi sebagian besar memengaruhi reaksi para pemangku kepentingan terhadap tindakan dan produk korporasi tertentu (Adeniji et al., 2014). Sedangkan menurut Rayner (2003), citra perusahaan memberikan keuntungan dan hak istimewa yang jelas pada perusahaan. Ini terbukti sulit untuk ditiru, sekaligus menciptakan tanggung jawab. Padahal, kewajiban yang dimiliki manajer dan organisasi harus memenuhi standar pribadi karyawan, standar kualitas pelanggan, standar etika masyarakat dan standar profitabilitas investor. Oleh karena itu, organisasi mempertahankan citra perusahaan dengan membangun hubungan yang kuat dan mendukung dengan semua pelanggan, pemasok, investor, masyarakat, pemerintah, (Van Riel \& Fombrun, 2007)

Di- Samping itu, Villanova, Zinkhan dan Hyman (2000), menyatakan bahwa "Citra perusahaan adalah persepsi keseluruhan perusahaan yang dimiliki oleh berbagai segmen masyarakat". Sebagai contoh, produk dan layanan yang dibeli oleh para pemangku kepentingan konsumen dipandang sebagai memiliki makna pribadi dan sosial di samping utilitas fungsional (Adetunji et al., 2018).

Dengan demikian dapat dikatakan bahwa citra adalah persepsi mental orang yang terkait dengan suatu Obyek, Produk, Layanan, individu atau organisasi. Citra tidak perlu benar dan citra hanyalah indikasi bahwa bagaimana seseorang dipersepsikan oleh orang lain. Organisasi memang memiliki citra di benak publik, pelanggan, karyawan, pemerintah atau dalam hal ini dalam kelompok yang berkepentingan. Berapa organisasi menikmati dari citra yang menguntungkan, di mana beberapa organisasi tidak menikmati citra yang menguntungkan. Citra bermanfaat bagi organisasi untuk mencapai tujuannya. Ada banyak gambar yaitu, Ramah, Cepat, Jujur, Koruptif, Efisien. Jadi tidak dapat dikatakan citra mana yang benar atau citra yang salah, dan dapat mengatakan beberapa citra menguntungkan organisasi untuk mencapai tujuannya dengan kemudahan relatif

Jenis-jenis Citra

Frank Jefkins

menyatakan ada 5 jenis citra yang harus dipahami oleh praktisi Public Relations, yaitu: 1. Citra bayangan adalah citra yang melekat pada orang dalam atau anggota organisasi yaitu anggapan pihak luar tentang perusahaan. 2. Citra yang berlaku adalah citra yang dipercaya oleh 
pihak luar mengenai suatu perusahaan. 3. Citra yang diharapkan adalah citra yang diharapkan pihak manajemen. 4. Citra perusahaan adalah citra dari perusahaan secara keseluruhan, bukan termasuk citra atas produk dan pelayanannya. 5 . Citra majemuk, adalah citra yang timbul yang belum tentu sama dengan perusahaan secara keseluruhan karena banyaknya jumlah karyawan, cabang atau perwakilan dari suatu perusahaan(Ruliana Poppy, 2016)

Pameran

\section{Praktisi Public Relations} memainkan peran penting dalam pelaksanaan pameran dan perlu menyampaikan citra perusahaannya secara positif kepada para pengunjung, dan mempromosikan produk atau layanan apapun yang ditawarkan organisasi, tanpa memaksa siapa pun untuk membeli produk atau layanan itu.

Upaya yang harus dilakukan oleh praktisi Public Relations adalah sebagai berikut: Pertama, memberitahu calon klien pameran sebelum dan selama pertunjukan, kedua, mendapatkan liputan media yang positif untuk organisasi, dan ketiga, mendapatkan liputan tindak lanjut dan umpan balik setelah pameran berlangsung (Laricia, 2002).

Freed E. Han dan Kenneth G. Mangun menjelaskan bahwa
"Pameran adalah suatu alat pemasaran yang efektif yang bertujuan untuk mempromosikan produk tertentu, menginformasikan program perusahaan, tentang keunggulan suatu produk kepada khalayak, sekaligus sebagai upaya untuk meningkatkan penetrasi pasar (Mozes, 2020)

\section{Metode Penelitian}

Penelitian ini menggunakan pendekatan kualitatif. Taylor dan Bogdan dalam (dalam Ruliana, Dwiantari, 2015) menjelaskan bahwa penelitian kualitatif adalah penelitian untuk mendapatkan hasil berupa data deskriptif tentang kata-kata baik secara lisan maupun secara tertulis, dan perilaku yang diamati dari individu-individu yang diteliti. Jensisi penelitian yang digunakan adalah deskriptif, menggambarkan realitas yang aktual dan tidak menjelaskan hubungan antar variabel (Kriyantono, 2012) oleh karena itu untuk menjelaskan strategi PR dalam membangun citra perusahaan melalui pameran IIMS digunakan metode deskriptif kualitatif.

Teknik pengumpulan data dalam penelitian dilakukan melalui beberapa tahap, yaitu: Pertama, observasi partisipasi, tahap kedua, wawancara mendalam (in-depth interview) untuk mengecek ulang atau pembuktian terhadap informasi yang diperoleh sebelumnya. 
Informan kunci dalam penelitian ini adalah CEO PT Premium Motorindo Abadi, Public Relations Officier (PRO) PT Premium Motorindo Abadi, Manager marketing PT Premium Motorindo Abadi, dan 6 orang pengunjung pameran IIMS. Tahap ketiga, dokumentasi dalam bentuk data atau fakta yang tersimpan di server dan flashdisk, atau website(Bungin, 2011).

Teknik Analisis data dalam penelitian ini menggunakan model interaktif dari Miles dan Huberman yang dilakukan dalam tiga tahap, yaitu : (a). Tahap reduksi data (b). Tahap penyajian data (c). Tahap penarikan kesimpulan atau verifikasi (Sugiyono, 2016).

\section{Hasil Penelitian dan Pembahasan}

Untuk menjawab tujuan penelitian ini yaitu untuk menjelaskan strategi Public Relations dalam membangun citra perusahaan melalui program pameran IIMS. Peneliti melibatkan informan kunci, yaitu JT selaku CEO PT Premium Motorindo Abadi selaku pelaku pengambil keputusan dan didukung juga oleh informan lain yaitu RAP selaku Public Relations Officer (PRO) dan AD Sales \& Marketing Manager PT Premium Motorindo Abadi serta 6 orang pengunjung pameran IIMS yaitu AZ.MI.SH.ZR.MT dan SH yang dipilih secara purposive.
Konsep strategi Public Relations yang digunakan adalah konsep dari Cutlip, Center \& Broom yaitu fase pertama mendefinisikan masalah, fase kedua, perencanaan dan pemrograman, fase ketiga adalah mengambil tindakan dan berkomunikasi dan fase keempat adalah evaluasi program. Konsep citra mengacu pada pendapat Villanova, Zinkhan dan Hyman (2000), menyatakan bahwa citra perusahaan adalah persepsi keseluruhan perusahaan yang dimiliki oleh berbagai segmen masyarakat.

PT Premium Motorindo AbadI menekuni bisnis otomotif sepeda motor berjenis Offroad dan Streetbike dengan merk atau brand Husqvarna dan KTM dan merupakan Perusahaan Importir atau Agen Pemegang Merek (APM) yang mendistribusikan dan memasarkan produk Motorcycle dengan nama brand Husqvarna dan KTM di Indonesia sejak tahun 2017. PT Premium Motorindo Abadi memiliki visi dan misi, menurut JT visi dan misi adalah sebagai berikut:

Visinya menjadi perusahaan
terkemukar dalam ridang
penjualan motor Nasional
maupun International. Bertujuan
menjadi Importer Dirtbike atau
Bigbike untuk brand Husqvarna
dan KTM terbesar di Asia
Tenggara pada tahun 2025.
Sedangkan misinya 1.
Menjalankan fungsi manajerial

Visinya menjadi perusahaan terkemuka dalam bidang penjualan motor Nasional maupun International. Bertujuan menjadi Importer Dirtbike atau Bigbike untuk brand Husqvarna dan KTM terbesar di Asia Tenggara pada tahun 2025. Menjalankan fungsi manajerial 
perusahaan secara professional dengan prinsip memberikan pelayanan terbaik kepada seluruh stakeholders. 2. Melakukan pengembangan kompetensi dan keterampilan seluruh karyawan secara berkala sesuai perkembangan teknologi informasi dan komunikasi. 3. Menciptakan iklim dan budaya organisasi yang kondusif dan produktif guna mendorong motivasi kerja yang positif. 4. Melaksanakan kegiatan Corporate Social Responsibility sebagai bentuk tanggung jawab sosial perusahaan kepada masyarakat (Informan Kunci, JT, 2020)

Untuk mewujudkan visi dan misinya tersebut, diperlukan perencanaan, dan strategi pencapaian yang terarah. Menurut JT CEO PT Premium Motorindo Abadi diperlukan perencanaan jangka panjang untuk mencapai visi adalah sebagai berikut:

Memperluas jaringan dealer dan aftersales yang tersebar di seluruh Indonesia dilengkapi dengan Workshop yang dilengkapi dengan special Tools dan Diagnostic Tablet Xc2 yang bertujuan memberikan pelayanan secara lebih maksimal kepada seluruh customer produk motorcross Husqvarna dan KTM. (Informan kunci JT, 2020)

Visi dan misi tersebut menggambarkan komunikasi internal perusahaan. Dan visi dibuat biasanya oleh pimpinan perusahaan atau CEO seperti yang dikemukakan oleh Cutlip,Center \& Broom bahwa biasanya diciptakan di level tertinggi dalam organisasi oleh CEO atau anggota koalisi dominan lainnya dan pernyataan visi merepresentasikan tujuan global yang menjelaskan prioritas umum yang dikejar organisasi. Pernyataan visi yang efektif akan menjawab pertanyaan dasar berikut ini; "Mengapa organisasi itu ada" dan "Apa yang akan kita cari”, visi bersama adalah bagian integral dari kultur sebuah organisasi dan dikomunikasikan melalui hubungan internal. Pernyataan visi mengungkapkan sasaran strategis dan tujuan masa depan dari sebuah organisasi (Ruliana, 2014).

Sedangkan pernyataan misi menjawab pertanyaan "Bagaimana kita berbeda dengan pesaing kita?", pernyataan misi memberikan tujuan, struktur, dan strategi organisasi, legitimasi, nilai, partisipasi dan kepemilikan di antara karyawan, kepemimpinan, tanggung jawab kepada komunitas, prioritas etis, dan komitmen kepada publik dan stakeholder (Ruliana, 2014).

Oleh karena itu setiap perencanaan program yang akan dilaksanakan harus sesuai dengan visi dan misi PT Premium Motorindo Abadi dan mendapat persetujuan CEO sebagai pengambil keputusan, dan proses komunikasi baik secara internal maupun eksternal mengalir secara hierarki sesuai dengan struktur organisasi dan posisi Public Relations yang secara strategis berperan sesuai fungsi, tanggung jawab masing-masing divisi.

Atas dasar visi dan misi PT Premium Motorindo Abadi tersebut di atas, Public Relations melakukan kegiatan komunikasi dalam bentuk 
pameran sebagai salah satu strategi Public Relations dalam membangun citra perusahaan, dan melalui program pameran IIMS, penting melibatkan proses empat fase yang dikemukakan oleh Cutlip, Center \& Broom (2009) untuk menyelesaikan masalah dan kemungkinan dapat membangun citra perusahaan (Broom \& Sha, 2013).

Fase 1: Mendefinisikan Masalah (Defining Public Relations Problems)

Dalam upaya memenangkan persaingan bisnis dan upaya merebut pelanggan, PT Premium Motorindo Abadi melakukan berbagai aktivitas untuk menghasilkan peningkatan kesadaran merek atau brand awareness dan sekaligus membangun citra perusahaan di tengah masyarakat. Dari hasil wawancara yang dilakukan dengan JT, PR dan AD Abadi dikemukakan mengapa PT Premium Motorindo Abadi ikut dalam pameran IIMS. Ada pun permasalahannya adalah sebagai berikut:

Permasalahan yang muncul mengapa PT Premium Motorindo Abadi ikut dalam pameran IIMS adalah semakin bermunculannya perusahaan-perusahaan yang menjalankan bisnis sejenis, sehingga memunculkan persaingan bisnis diantara perusahaan-perusahaan tersebut dan segmentasi yang terbatas karena jenis motor yang dipasarkan memiliki high selling value (Wawancara Informan kunci JT, dan informan RAP dan AD, 2020).

Pendapat yang dikemukakan oleh Public Relations PT Premium Motorindo Abadi tersebut diperoleh dari hasil survei yang dilakukan kepada konsumen yang dijadikan segmentasi sasaran dan mengumpulkan berbagai informasi yang diperoleh dari pemberitaan di media massa dan media online tentang perkembangan dunia otomotif sepeda motor yang begitu kompetitif. Dari hasil penelitian inilah maka dilakukan suatu strategi untuk mempromosikan sekaslgus memasarkan sepeda motor KTM dan Husqvarna yaiu turut serta dalam pameran IIMS sebagai salah satu cara untuk mengatasi masalah tersebut. Seperti yang dikemukakan informan kunci berikut ini:

Mengikuti exhibtion, seperti
IIMS. Kehadiran PT Premium
Motorindo Abadi dalam pameran
otomotif yang menghadirkan
brand motor offroad Husqvarna
\& KTM dengan identitas merek,
dan logo dinilai memiliki
pengaruh yang besar bagi
perusahaan serta bagi
Komunitas Offroad (Informan
Kunci, IT, 2020).

Dalam fase ini pengetahuan, pendapat, sikap, dan perilaku semuanya terkait dengan prosedur dan kebijakan perusahaan diteliti. Ini menciptakan dasar untuk semua fase lain dalam memecahkan masalah dalam membangun citra. 


\section{Fase 2: Perencanaan Dan Pemrograman (Planning and Programming)}

Informasi yang dikumpulkan pada fase pertama digunakan untuk pengambilan keputusan tentang pemangku kepentingan, tujuan spesifik, gerakan dan strategi komunikasi, taktik dan tujuan umum. Itu berarti hasil dari fase pertama dimasukkan ke dalam kebijakan dan program PT Premium Motorindo Abadi. Oleh karena itu dibutuhkan perencanaan dan pemograman yang terencana dan terkoordinir dengan baik, seperti yang dikemukakan oleh informan yang menyatakan bahwa:

Perencanaan pameran IIMS yang dibuat atas persetujuan CEO dan melakukan koordinasi dengan divisi terkait serta membentuk teamwork. Manajemen sangat mendukung terhadap program pameran IIMS, seperti membentuk (1) Team Acara Hiburan. (2) Team Sales dan Marketing (3) Team Digital Marketing (4) Team Graphic Design (5) Management Internal. (6) Management External seperti Dealer di seluruh Indonesia (Informan $R A P$ dan AD, 2020).

Perencanaan tersebut menggambarkan program komunikasi internal dan komunikasi eksternal secara terarah dan sistematis dengan menginformasikan terlebih dahulu kepada para konsumen dan pelanggan sebelum pameran dilaksanakan dan menghubungi media untuk meliput perusahaan dan mendapat liputan positif sebagai tindak lanjut dan umpan balik yang diperoleh dari para pengunjung pameran yang datang ke stand PT Premium Motorindo Abadi. Hal ini sesuai dengan yang dikemukakan oleh Laricia Smith bahwa upaya yang harus dilakukan oleh praktisi Public Relations, pertama, memberitahu calon klien pameran sebelum dan selama pertunjukan, kedua, mendapatkan liputan media yang positif untuk organisasi, dan ketiga, mendapatkan liputan tindak lanjut dan umpan balik setelah pameran berlangsung (Laricia, 2002).

Langkah-langkah tersebut, dilaksanakan untuk telah ditetapkan. Ada pun tujuannya menurut $P R O$ adalah sebagai berikut:

Untuk memperluas market offroad di Indonesia melalui pameran, masyarakat akan mengenal dan belajar langsung mengenai offroad bike melalui sales dan marketing yang benarbenar mengenal offroad bike serta mempersuasi masyarakat untuk menyukai olahraga otomotif dan membangun citra PT Premium Motorindo Abadi (informan RAP, 2020).

Sedangkan pelaksanaan program dimana Public Relations dan tim kerja PT Premium Motorindo Abadi menyesuaikan dengan waktu pelaksanaan pameran IIMS yang berlangsung pada tanggal 25 April hingga 5 Mei 2019 berlokasi di JIExpo, Kemayoran, Jakarta. Persiapan dalam pelaksanaan program menurut RAP yaitu:

Mempersiapkan press release mengenai launching Motor Terbaru. Mengedukasi 
masyarakat melalui press release yang dibuat. Memperkenalkan teknologi injeksi pada tipe motor $300 c c$ dua tak Enduro. Pada motor Husquarna. (informan RAP,2020).

Program yang dilaksanakan oleh PT Premium Motorindo Abadi tersebut didasarkan pada perencanaan yang telah ditetapkan. Persiapan press release dimaksudkan untuk media yang akan meliput dan membangun kerjasama dengan pers atau media sebagai salah satu strategi. Adapun media yang digunakan dalam pelaksanaan pameran IIMS ini adalah:

media above the line seperti media cetak, media elektronik, media below the line seperti: brosur, katalog, kalender, kartu nama, company profile, buku agenda, paperbag, dan lainlain, dan outdoor media serta internet / website kerjasama, diantaranya dengan otomotif.okezone.com,

Detik.com, Viva.com, otomotif.kompas.com.

(Informan RAP,2020).

Jenis media tersebut digunakan sebagai communication channels dalam pelaksanaan pameran, bertujuan untuk kepentingan sosialisasi branding, edukasi, promosi dan publikasi, pembentukan citra positif perusahaan dan produk serta media efektif untuk membangun brand image Husqvarna dan KTM.

Fase dalam perencanaan dan pemograman yang dilakukan oleh PRO tersebut, sesuai dengan apa yang dikemukakan oleh Cutlip, Center, \& Broom yang menjelaskan bahwa "Perencanaan merupakan perincian secara teratur dan berurutan tentang langkah-langkah yang akan dilaksanakan untuk mencapai tujuan tertentu. Programming adalah susunan acara, yaitu perincian waktu atau timing secara teratur dan menurut urutan tertentu tentang pelaksanaan langkah demi langkah sesuai dengan apa yang telah ditetapkan dalam planning. Selain sebuah perencanaan dan program yang sedemikian matang, tapi tak ideal apabila tidak ada unsur publikasi, maka Public Relations harus cerdas mengetahui media apa yang akan digunakan dalam menunjang kegiatan Public Relations tersebut" (Ruliana, Dwiantari, 2015).

Fase 3: Mengambil Tindakan dan Berkomunikasi (Taking Action and Communicating)

Dalam fase ini, program tindakan dan komunikasi harus mencapai tujuan spesifik untuk setiap publik sebagai prasyarat untuk realisasi tujuan umum program pameran IIMS yang dilakukan oleh PT Premium Motorindo Abadi.

Penyusunan strategi yang dilakukan adalah strategi aktif yang terbagi menjadi dua, yaitu strategi aksi dan strategi komponen komunikasi, seperti yang dijelaskan PRO berikut ini:

Strategi aksi: (1) Melakukan kerjasama dengan Penyelenggara Pameran IIMS dan perusahaan Star Hub, (2) bekerjasama dengan pers atau media dengan membuat press release untuk peliputan media pada saat 
pameran untuk memperoleh citra positif. Sedangkan strategi komponen komunikasi: menentukan komunikator yang memiliki kredibilitas untuk membuka acara, seperti CEO, komisaris PT Premium Motorindo Abadi atau tokoh olah raga offroad, memilih pesan yang informatif, persuasif dan edukatif mengenai produk motor merek KTM dan Husqvarna agar memiliki daya tarik yang tinggi pada audience yang dijadikan sasaran dan menimbulkan efek kognitif, afakrif dan perilaku sehingga mengambil keputusan untuk membeli dan memberikan penilaian sehingga terjadi mutual understanding.

$R A P, 2020)$..

(informan

bawah bagaimana strategi aksi dan komponen komunikasi diterapkan dimana bagian Marketing Manager PT Premium Motorindo Abadi sedang diwawancarai oleh wartawan

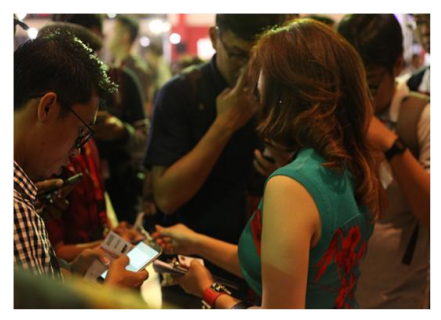

Gambar 2: Wawancara dengan Media Sumber : PT Premium Motorindo Abadi, 2020

Sedangkan strategi komponen

komunikasi dimana CEO dan

komisaris PT Premium

Motorindo Abadi akan

memberikan pidato pada

pelaksanaan pameran IIMS dan mendapat sambutan yang baik dari audience yang hadir di stand tersebut.

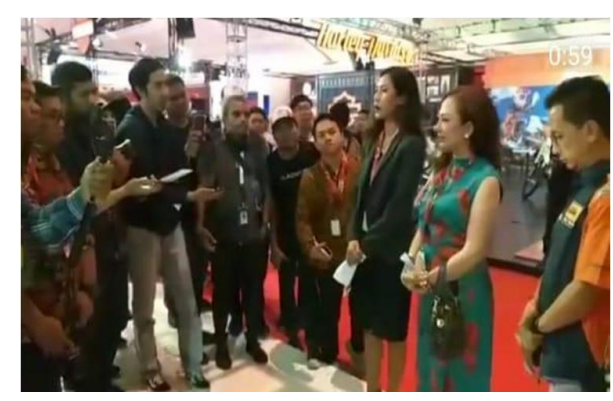

Gambar 3 : Pidato Pembukaan Pameran IIMS stand KTM dan Husqvarna Sumber : PT Premium Motorindo Abadi, 2020

Pesan yang disampaikan kepada para pengunjung dirumuskan terlebih dahulu sehingga dapat menarik perhatian pengunjung, $P R O$ menjelaskan bahwa:

PT Premium Motorindo Abadi melakukan packaging pesan terhadap produk atau brand dengan mendesain logo yang menarik dengan mengemas tagline atau slogan produk Husqvarna dan KTM yang dapat menarik calon customer untuk membeli produk karena Husquarna dan KTM Dirtbike \& Streetbike hadir di Indonesia melalui PT Premium Motorindo Abadi sebagai importir untuk mendukung masyarakat yang gemar berolahraga khususnya olahraga bermotor (Informan RAP, 2020) 
Adapun logo kedua jenis merek motor tersebut, seperti yang terlihat dalam gambar di bawah ini:

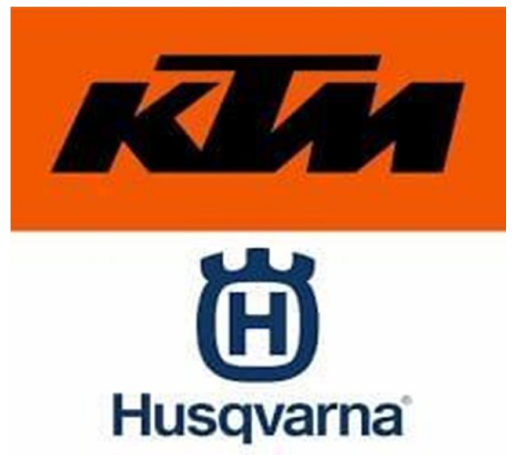

Gambar 1 : Logo KTM dan Husqvana Sumber : PT Premium Motorindo Abadi, 2020

KTM memiliki Motto: "Ready To Race”. Motto ini memiliki makna bahwa motor-motor yang kami jual adalah motor-motor yang mempunyai performance tinggi, adventure (lifestyle dan extreme), tahan segala medan, dan mempunyai kekuatan yang sangat prima disegala kondisi, terbaik dan akan memberikan kepuasan tersendiri bagi customer kami. Sedangkan motto Husqvarna adalah "Pioneering Since 1903". Memiliki makna bahwa "Husqvarna" merupakan pelopor produsen mesin-mesin bermotor sejak tahun 1903 yang berasal dari Swedia (Informan RAP, 2020).

Logo mencirikan identitas merek dari masing-masing jenis motor yang dipamerkan seperti merek Husqvarna dan KTM, seperti terlihat dalam gambar di bawah ini:
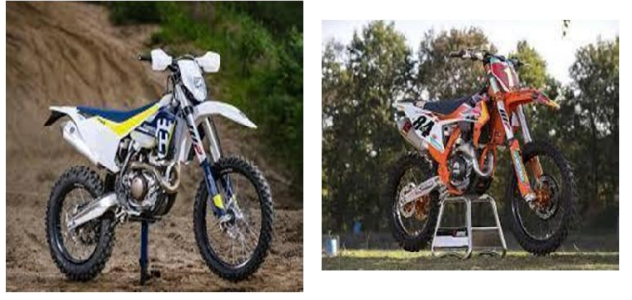

Gambar 4 : Motor Husqvarna dan KTM Sumber : PT Premium Motorindo Abadi 2020

\section{Fase 4: Evaluasi Program (Evaluating The Program)}

Untuk mengevaluasi dari fase persiapan ini, implementasi dan hasil program dievaluasi. Penyesuaian didasarkan pada umpan balik pada efisiensi atau tidak ada efisiensi. Untuk mengetahui efek dan umpan balik atau feedback dari penyelenggara pameran, PT Premium Motorindo Abadi melakukan riset opini berupa survei karena untuk membangun citra perusahaan (corporate image) sangat penting untuk mengetahui persepsi khalayak, dalam hal ini pengunjung pemeran. Seperti yang dikemukakan Villanova, Zinkhan dan Hyman (2000), bahwa "Citra perusahaan adalah persepsi keseluruhan perusahaan yang dimiliki oleh berbagai segmen masyarakat". Oleh karena itu, efek atau feedback dari pameran ini agar memperoleh citra perusahaan yang positif adalah sangat penting.

Survei dilakukan 6 (enam) orang pengunjung yang terpilih yaitu FH. MT. AZ. ZR. MI. SH, gambar berikut mendeskripsikan proses pengisian angket atau kuesioner kepada informan 
terpilih. Seperti tampak dalam gambar di bawah ini.

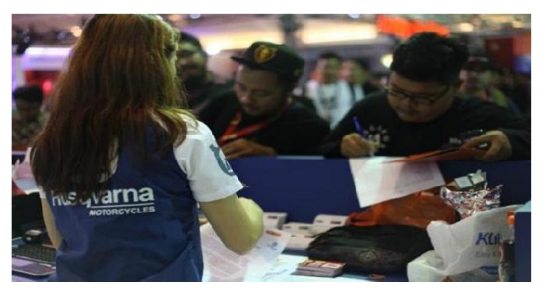

Gambar 5 : Pengisian Kuesioner pengunjung Sumber : PT Premium Motorindo Abadi, 2020

Informasi yang diperoleh dari para informan sebagai pengunjung pameran IIMS mengenai perencanaan program yang dilakukan oleh PT Premium Motorindo Abadi, mereka mengatakan:

Perencanaannya dilakukan
dengan koordinasi yang baik
dengan menempatkan personil
yang professional dan
memperkenalkan produk yang
premium dalam ajang pameran
IIMS yang bergengsi di tanah air
dan lokasi stand pada posisi
yang strategis sehingga mudah
dilihat.

(FH. MT. AZ SH. Informan pengunjung, 2020).

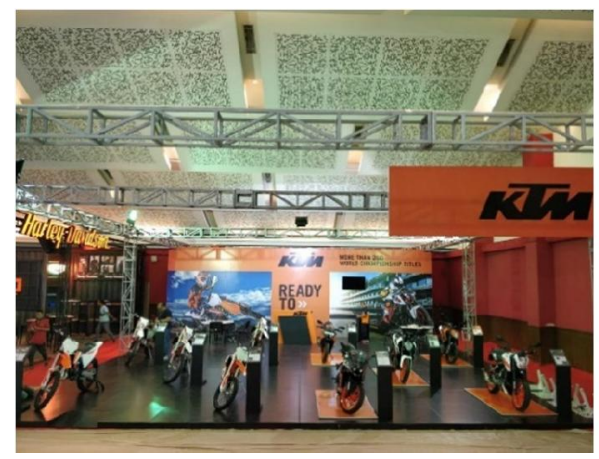

Gambar 7 : Stand KTM dan Husqvarna Sumber : PT Premium Motorindo Abadi, 2020
Jadi dapat dikatakan bahwa Public Relations PT Premium Motorindo Abadi telah membuat perencanaan komunikasi dengan baik dan terarah dengan tema branding yang unik dan sparasi warna yang menarik mencerminkan identitas perusahaan PT Premium Motorindo Abadi dan produk motor KTM dan Husquarna yang memiliki daya tarik pesan yang tinggi.

Pendapat lain dikemukakan oleh FH. MT. AZ SH. bahwa:

Motor tersebut memiliki nilai yang tinggi dan segmen atas, bagi saya motor KTM dan Husqvarna adalah impian orang-orang yang memiliki lifestyle yang tinggi dan dengan memiliki salah satu motor tersebut menunjukkan identitas orang yang menggunakan motor tersebut. (Informan pengunjung,2020)

Disini jelas terlihat bahwa segmentasi sasaran kedua jenis produk motor tersebut adalah kalangan atas. karena harga yang ditawarkan sangat tinggi dan pengunjung yang membeli motor tersebut memiliki identitas yang juga tinggi. Mereka rata-rata tertarik untuk membeli tetapi mempertimbangkan kondisi keuangan. Berikut adalah pernyataan mereka:

Tertarik membeli motor karena sangat dibutuhkan di lingkungan kerja saya, yang medan dan jalur transportasi masih cukup terbatas dan sedang mempersiapkan dana untuk membeli salah satu tipe motor tersebut.

(Informan AZ. MT.FH. 2020). 
Selanjutnya, ketika ditanya mengenai pelayanan yang diberikan, FH. MT. AZ. ZR.MI.SH mengemukakan bahwa

mereka ramah dan professional
juga responsiver dan
menawarkan delivery motor
yang cepat sesuai dengan
pesanan

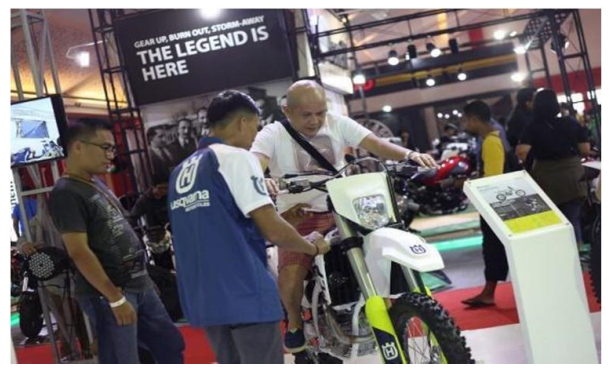

Gambar 6 : Pelayanan terhadap pengunjung Sumber : PT Premium Motorindo Abadi, 2020

Pendapat atau opini pengunjung secara keseluruhan mengenai program pameran IIMS khususnya stand pameran produk motor merek KTM dan Husqvarna mereka mengatakan:

Secara keseluruhan baik dan buktinya memperoleh penghargaan roda dua terbaik dan stand terbaik sehingga mencerminkan citra perusahaan yang baik.

(Informan pengunjung,2020)

Apa yang dikemukakan oleh para informan tersebut mendeskripsikan feedback yang sangat penting bagi PT Premium Motorindo Abadi, dan hasilnya melalui pameran IIMS, yakni terjalinnya komunikaksi dua arah (two way communication) sehingga menimbulkan keakraban pengunjung sebagai pembeli, atau calon pembeli, serta kepuasan pelanggan yang loyal atas program promosi yang diberikan pada saat pameran berlangsung. dan mengedepankan delivery motor kepada pelanggan karena itulah memperoleh respon yang positif.

Feedback lainnya jumlah pengunjung yang datang ke stand sepeda motor Husqvarna dan KTM dapat dikatakan banyak yang datang mengunjungi, dapat dalam gambar berikut ini;

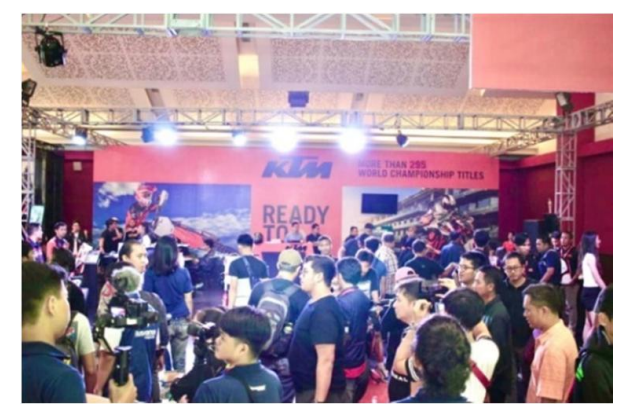

Gambar 7 : Pengunjung Stand Husqvarna Sumber : PT Premium Motorindo Abadi, 2020

Berdasarkan gambar diatas alasan pengunjung datang ke stand KTM \& Husqvarna dikarenakan ketertarikan dalam melihat produk baru yang di luncurkan oleh PT Premium Motorindo Abadi, Yaitu motor FC 450 Rockstar Factory Editon, yang di gunakan oleh para pembalap pabrikan tim Husqvarna di MXGP.

Di samping itu, PT Premium Motorindo Abadi terbukti memperoleh pemberitaan di media cetak online, seperti Kompas.com,Antara News Otomotif, Liputan 6, Suara Republika dan lainlain. Adapun data media yang meliput dan memberitakan tentang pameran Husqvarna dan KTM dapat dilihat dalam tabel yang 
menggambarkan keberhasilan dalam pelaksanaan pameran produk motor IIMS dan dapat dikatakan berhasil dalam membangun citra perusahaan
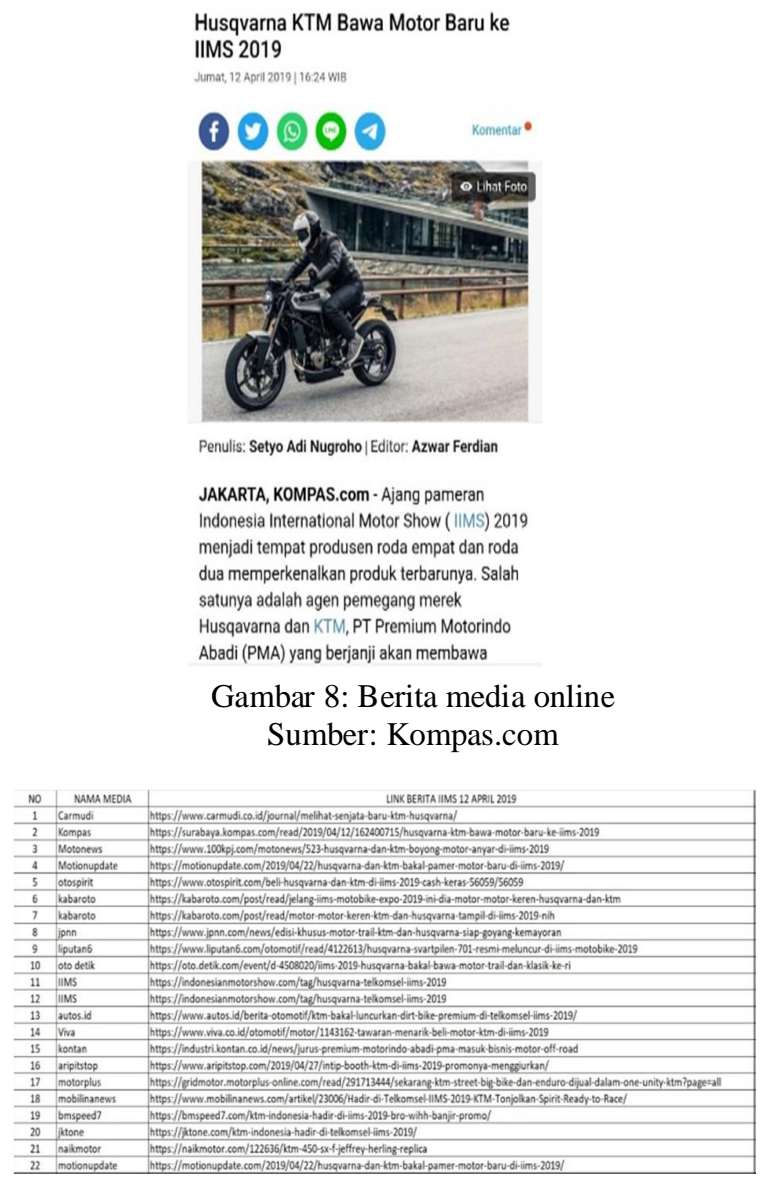

Gambar 9 : Table list media online yang memberitakan PT PMA di ajang IIMS 2019

Sumber: PT Premium Motorindo Abadi

Kemudian pihak penyelenggara yaitu PT Dyandra Promosindo memberikan penghargaan pada PT Premium Motoriondo Abadi yang didasarkan pada persepsi atau penilaian pengunjung yang datang ke pameran IIMS seperti terlihat dalam gambar di bawah ini.

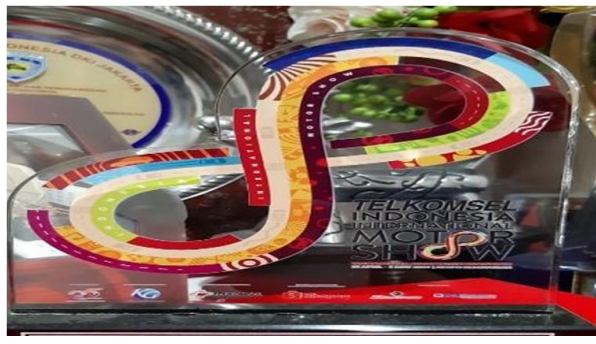

Gambar 9 : Piala Penghargaan Exhibiton Sumber : PT Premium Motorindo Abadi, 2019

Dengan demikian dapat dikatakan bahwa citra adalah persepsi mental orang yang terkait dengan suatu obyek, produk, layanan, individu atau organisasi. Citra tidak perlu benar dan citra hanyalah indikasi bagaimana seseorang dipersepsikan oleh orang lain. PT Premium Motorindo Abadi memang memiliki citra di benak publik, pelanggan, karyawan, pemerintah atau dalam hal ini kelompok yang berkepentingan. Beberapa organisasi menikmati dari citra yang menguntungkan. Citra bermanfaat bagi perusahaan untuk mencapai tujuannya. Ada banyak citra yaitu, Ramah, Cepat, Jujur, Koruptif, Efisien. Jadi tidak dapat dikatakan citra mana yang benar atau citra yang salah, dan dapat mengatakan beberapa citra menguntungkan organisasi untuk mencapai tujuannya dengan kemudahan relative (Palaniappan \& Ramachandraiah, 2012). 


\section{Simpulan}

Strategi Public Relations PT Premium Motorindo Abadi dalam melaksanakan program pameran IIMS, harus dimulai dari fakta bahwa misi dasar mengenai kegiatankegiatan ini adalah untuk membangun citra perusahaan. Namun, harus diperhitungkan bahwa citra perusahaan adalah hasil dari semua kegiatan "nyata" dan semua kegiatan komunikasi di mana perusahaan mentransmisikan pesan kepada publik yang relevan. Oleh karena itu, setiap fase yang digunakan dalam strategi Public Relations dalam membangun citra perusahaan mendukung penelitian ini. Hal ini sesuai dengan yang dikemukakan Argenti (2009) bahwa strategi Public Relations memiliki pengaruh terbesar pada citra perusahaan. (Argenti, 2009). Jadi strategi membutuhkan pilihanmemutuskan jenis nilai tertentu yang ingin diberikan oleh organisasi dan kepada khalayak yaitu citra perusahaan. Temuan dalam penelitian ini adalah strategi komunikasi terintegrasi yang dapat dilakukan oleh peneliti lain dengan permasalahan, konsep dan metode yang berbeda.

\section{Daftar Pustaka}

Adetunji, R. R., Rashid, S. M., \& Ishak, M. S. (2018). Social media marketing communication and consumer- based brand equity: An account of automotive brands in Malaysia. Jurnal Komunikasi: Malaysian Journal of Communication. https://doi.org/10.17576/JKMJC -2018-3401-01

Argenti, P. (200Adeniji, A., Osibanjo, A. O., Abiodun, A. J., $\&$ Oni-Ojo, E. E. (2014).

Corporate image: A strategy for enhancing customer loyalty and profitability. Vision 2020:

Sustainable Growth, Economic Development, and Global Competitiveness - Proceedings of the 23rd International Business Information Management Association Conference, IBIMA 2014, 1, 1687-1695. https://doi.org/10.5171/2015.25 9483

Broom, G. M., \& Sha, B.-L. (2013). Cutlip and Center's Effective Public Relations. In Cutlip and Center's Effective Public Relations.

Bungin. (2011). Metodologi Penelitian Kuantitatif. Kencana Prenada Media Group.

Mikáčová, L., \& Gavlaková, P. (2014). The Role of Public Relations in Branding. Procedia - Social and Behavioral Sciences, 110, 832-840. https://doi.org/10.1016/j.sbspro. 2013.12.928

Kriyantono. (2012). Teknis Praktis Riset Komunikasi. Kencana Prenada Media Group. Laricia, S. (2002). Exhibitions - a Public Relations tool. BIZCOMMUNITY. https://www.bizcommunity.com /Article/196/94/766.html 
Lengkong, S. L., Sondakh, M., \& Londa, J. . (2017). Strategi Public Relations Dalam Pemulihan Citra Perusahaan (Studi Kasus Rumah Makan Kawan Baru Megamas Manado). Acta Diurna, VI(1), $1-46$.

https://ejournal.unsrat.ac.id/inde x.php/actadiurnakomunikasi/arti cle/view/15493/15034

MOZES, R. A. (2020). Pameran: Pengertian, Tujuan, Manfaat dan Fungsi Halaman all Kompas.com. Kompas.Com. https://www.kompas.com/skola/ $\mathrm{read} / 2020 / 01 / 24 / 210000069 / \mathrm{pa}$ meran--pengertian-tujuanmanfaat-dan-fungsi?page $=$ all

Mujianto, H. (2018). Pengaruh Strategi Public Relations Terhadap Citra Perusahaan. Jurnal Komunikasi Hasil Pemikiran Dan Penelitian, 4(1), 88-96. https://doi.org/://dx.doi.org/10.1 0358/jk.v4i1.360

Palaniappan, S. N., \& Ramachandraiah, S. A. M. (2012). Training Programme on Public Relations. 95-130.

Putu, N., Nindya, A., Ayu, I. D., Joni, S., \& Devia, A. (2018). Strategi Humas Dalam Membangun Citra Perusahaan ( Studi Pada Indonesia Tourism Development Corporation, Bali ). E-Jurnal Medium, 1 No 2 201, 1-11.

https://ojs.unud.ac.id/index.php/ komunikasi/article/view/41867

Ruliana, Dwiantari, R. (2015). Strategi Public Relations Hotel dalam Membentuk Citra Objek Wisata. Jurnal ASPIKOM, 2(4), 255. https://doi.org/10.24329/aspiko m.v2i4.76

Ruliana. (2014). Komunikasi Organisasi:Teori dan studi Kasus. In Jakarta: Rajawali pers

Ruliana Poppy. (2016). Komunikasi Organisasi, Teori dan Studi Kasus, Edisi Kedua. RajaGrafindo Persada. http://www.rajagrafindo.co.id/pr oduk/komunikasi-organisasi/

Senija, Sehannovic, D. T. (2015). the Role of Public Relations Strategy in Creating Corporate Image of B \& H Construction Companies. Research Expert Conference with International Perticipations Quality 2015, 10-13. https://pdfs.semanticscholar.org/ 040f/e16e191774e841ffcd84df6 2c8ab5feec649.pdf

Steyn, B. (2000). Model for developing corporate communication strategy. Communicare: Journal for Communication Sciences in Southern Africa, 19(2), 1-33. http://reference.sabinet.co.za/sa _epublication_article/comcare_ v19_n2_a2

Sugiyono. (2016). Memahami Penelitian Kualitatif. Bandung: Alfabeta.

Van Riel, C. B. M., \& Fombrun, C. J. (2007). Essentials of Corporate Communication. In Essentials of Corporate Communication. https://doi.org/10.4324/9780203 390931 